\title{
PSYCHE
}

\begin{tabular}{lll}
\hline VOL. XXV1 OCTOBER, 1919 & No. 5
\end{tabular}

\section{THE NEARCTIC PSAMMOCHARIDS OF THE GENUS APORINELLUS BANKS.}

By J. Bequaert,

American Museum of Natural History, New York City.

On one of the collecting trips made this summer with Prof. William M. Wheeler, in the vicinity of Boston, I collected a little Psammocharid which has proved to be an undescribed species of Aporinellus. In comparing this specimen with Mr. Nathan Banks' extensive collection of Psammocharids I have found another undescribed member of the same genus. Descriptions of both forms are given herewith, together with a brief review of the group. I am much indebted to Mr. Nathan Banks, of the Museum of Comparative Zoölogy, Cambridge, Mass., for the loan of rich material containing many types and for valuable bibliographic help.

The genus Aporinellus Banks ${ }^{1}$ includes small Psammocharinæ with the propodeum smooth, emarginate behind when seen from above, its posterior angles conical, sharp or obtusely rounded at the apex. Thorax convex above, the pronotum not flattened and shorter than or about the length of the mesonotum. The head is feebly flattened antero-posteriorly; the anterior margin of the clypeus straightly truncate. Tarsal comb of the fore legs well developed; the tibiæ and tarsi otherwise feebly spinose. Claws with a tooth about the middle of their length. There are no long erect hairs on the cheeks, gula, coxæ and propodeum. Fore wings with two closed cubital cells; the transverse median reaches the media before the origin of the basal vein; in the hind wings the transverse median ends before or close to the cubitus.

Aporinellus is represented by several species throughout the United States and also exists in Mexico; whether the genus occurs in Canada is not known. It is, however, probable that its range

1 Journ. New York Ent. Soc. 19, 1911, p. 223. 
includes several other zoölogical regions. Indeed, the genus Aporinellus as defined above, agrees with Kohl's "Group 14 of Pompilus Fabricius"1 and this identity was recognized by Sustera. ${ }^{2}$ Psammochares sexmaculatus (Spinola) of which I have seen a 9 from Corsica in Mr. Banks' collection, has the same structure of the propodeum as Aporinellus, but differs in the presence of a third, petiolate cubital cell in the fore wings; similar forms are apparently not known from the Nearctic Region.

Several of the species of Aporinellus have originally been described as Aporus. As shown by Banks the true Aporus Spinola is structurally very different and has thus far not been found in North America. I have examined two palearctic species, Aporus unicolor Spinola (the genotype) and A.dubius Van der Linden; in these the propodeum is not or scarcely emarginate behind and its lateral angles are not produced; the fore wings have two cubital cells and the transverse median ends on the media far beyond the basal. As suggested by Kohl, Aporus Spinola is more closely related to typical Psammochares Latreille (Pompilus Fabricius) with three cubital cells, from which it evidently has been derived. According to Banks, the true Aporus is also structurally close to the North American Psammochares marginatus (Say). On the other hand, Ashmead's genus Aporus ${ }^{3}$ evidently possesses all the characteristics of Aporinellus Banks which are, however, not present in Aporus unicolor Spinola.

The wasps of the genus Aporinellus are not frequently met with; they are usually found while running about in search of their prey and seldom visit flowers. The nesting habits are only known of A. fasciatus, which was studied in Wisconsin by G. W. and E. G. Peckham. ${ }^{4}$ The ethology of this wasp agrees with that exhibited by most Psammocharids. The prey consists of spiders belonging to various genera (Phidippus, Attus, Mcovia) of the family Attidæ. The female first captures her spider which is slightly paralyzed, dragged to the nesting site and temporarily deposited on a leaf. She then makes a careful study of the locality to discover a suitable spot for her burrow. Often several burrows are started and abandoned before the final choice is made. "The one habit that this

1 Verh. zool.-bot. Ges. Wien 34,1884, p. 54.

2 Ibid. 62, 1912, p. 212.

3 Canadian Entom. 34, 1902, p. 87.

4 Wisconsin Geol. Nat. Hist. Survey Bull. No. 2, 1898, pp. 55-57. 
species can claim as peculiar to itself is that of filling up the partly made nests that it is about to abandon. We have never seen the sense of order carried to so high a point in any other wasp" (G. and E. Peckham). After digging is completed, the spider is dragged inside and the egg fastened to the side of the abdomen of the prey; the entrance is then carefully filled up. When finished the burrow is a small gallery running down obliquely for an inch and a half in the ground. The spider is only slightly affected by the poison of the sting, this wasp depending probably more upon packing her victim in tightly to keep it quiet.

The following key will aid in separating the females of the species known from the eastern and central states, all of which I have examined in nature. In addition there are several Californian species tabulated by Mr. Nathan Banks in a forthcoming paper.

1. Body almost entirely reddish; head except the clypeus, and antennæ beyond the second joint, black. Wings blackish at tip, the second cubital cell scarcely longer than broad. Face below, posterior margin of pronotum and apical fasciæ of the abdominal tergites feebly sericeous. Tarsal comb long. Length: 5 to $6 \mathrm{~mm}$. ( $\sigma^{\gamma}$ unknown)....... rufus Banks. Not reddish throughout......................

2. Legs, at least the hind pair, mostly reddish............ Body and legs entirely black, with sericeous or silvery pubescence..................................

3. Body silvery, with distinct sericeous apical fasciæ on the abdominal tergites. Color black; the mandibles in their middle, the hind tibiæ and femora entirely and the basal joints of the hind tarsi partly, reddish. Head and tarsal comb as in fasciatus, from which this species differs in the second cubital cell being only $1 \frac{1}{2}$ as long as broad. Length: 5 to $7 \mathrm{~mm}$. ( $\sigma^{\top}$ unknown) ............... ferrugineipes (Viereck).

Body smooth, very feebly pruinose, not sericeous, the abdomen without silvery fasciæ. Second cubital cell $\frac{1}{3}$ to $\frac{1}{2}$ as long as broad............................4.

4. First three abdominal segments and all the legs for the larger part reddish. Ocellar triangle little flattened, the lateral ocelli only feebly nearer to the eyes than to each other. Tar- 
sal comb short, its bristles less than half the length of the fore basitarsus. Length: $7 \mathrm{~mm}$. ( $\sigma^{7}$ unknown). wheeleri sp. nov. Black; apex of the first two abdominal tergites with a scarcely visible rufous tinge; hind tibiæ and femora entirely, and hind tarsi partly reddish. Ocellar triangle distinctly flattened, the lateral ocelli much farther from each other than from the eyes. Tarsal comb long, its bristles over half the length of the fore basitarsus. Length: $6.5 \mathrm{~mm}$. ( $\sigma^{\top}$ unknown)

banksi sp. nov.

5. Vertex as broad or slightly broader than the face below. Lateral ocelli nearer to the eyes than to each other. Second cubital cell over twice as long as broad. Abdomen with distinct silvery apical fasciæ. Length: $7-8 \mathrm{~mm}$. ( $\sigma^{7}$ unknown)...................... laticeps Banks.

Vertex narrower than face below; lateral ocelli hardly nearer to the eyes than to each other. Second cubital cell about twice

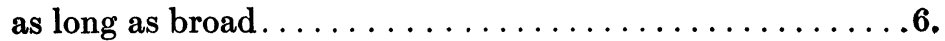

6. Body, except the apical two abdominal segments, uniformly sericeous. Posterior emargination of the propodeum feeble, the lateral angles small. Length: 5.5 to $6 \mathrm{~mm}$.

completus Banks.

Sericeous pubescence interrupted by black cross bands, especially on the second to fourth abdominal tergites which have distinct silvery apical fasciæ. Posterior angles of the propodeum very pronounced, large. Length: $\uparrow, 6$ to $8 \mathrm{~mm}$.; $\sigma^{7}, 4.5$ to $6.5 \mathrm{~mm}$................. fasciatus (Smith).

Aporinellus wheeleri sp. nov.

Female. Length $7 \mathrm{~mm}$.

Head distinctly broader than the thorax. Inner margins of the eyes subparallel below, feebly sinuate about the middle, then slightly converging towards the vertex which is much narrower than the face at the clypeus. Ocellar triangle very little flattened, almost equilateral; the lateral ocelli hardly nearer to the eyes than to each other. Clypeus straightly truncate at the anterior margin. Antennæ moderately slender; the third and fourth joints about of the same length and about as long as the scape. Pronotum convex, much shorter than the mesonotum when seen from above, its posterior margin broadly and evenly arcuate. 
Propodeum with pronounced apical emargination and acute lateral angles. Legs slender as compared with $A$. fasciatus, the femora and tibiæ hardly swollen. Comb of the fore tarsi feeble, composed of 5 or 6 short bristles, the longest of which are less than half the length of the fore basitarsus and about the length of the second tarsal joint. Fore wings with the second cubital cell comparatively short, slightly over $1 \frac{1}{3}$ as long as broad. Transverse median of the hind wings ending much before the base of the cubitus.

Head mostly and thorax entirely black; anterior margin of clypeus, mandibles except their apical teeth, and first antennal joint below, more or less reddish. Abdomen with the three first segments bright ferruginous red; the apical margin of the fourth tergite faintly reddish; the remainder black. Legs red; the coxæ, trochanters, extreme tips of femora and tibiæ, tibial spurs and larger part of the tarsi, black; the basitarsus and under side of trochanters on middle and hind legs suffused with red, and a red spot on the under side of the hind coxæ. Tarsal comb and erect bristles of tibiæ and tarsi black. Wings subhyaline; fore wings with a spurious cloud on the basal vein, their apical quarter infuscate.

Tegument impunctate, very shining. Body entirely without sericeous pile, clothed in a feeble grey pruinosity, which is a little more pronounced on the propodeum. No trace of abdominal silvery fasciæ. A few erect hairs on the clypeus, mandibles, and two apical segments of the abdomen.

Described from one female taken at Stony Brook Reservation, near Boston, Mass., July 12, 1919; it was sunning itself on a stony woodroad, after the usual Psammocharid manner.

This species is very striking in its coloration and its shining integument; its closest relative is undoubtedly the species described below as $A$. banksi.

Aporinellus banksi sp. nov.

Female. Length $6.5 \mathrm{~mm}$.

Head comparatively broader than in A. fasciatus, much broader than the thorax. Inner margins of the eyes subparallel near the clypeus, curved outwardly about the middle of the face, then feebly converging towards the vertex which is distinctly narrower 
than the face below. Ocellar triangle distinctly flattened; the lateral ocelli much nearer to the eyes than to each other and about as far from the anterior ocellus as from the eyes. Clypeus straightly truncate at the apex. Antennæ slender, the basal joint (scape) about the length of the fourth, which is a little shorter than the third. Pronotum a little shorter than the mesonotum, strongly convex. Propodeum with pronounced apical emargination; its lateral angles sharp, spinose (in $A$. fasciatus these angles are obtusely rounded at the tip). Legs slender as compared with $A$. fasciatus, the hind femora and tibiæ feebly swollen. Comb of the fore tarsi long, its longest bristles about half the length of the fore basitarsus. Fore wings with the second cubital cell much shorter than in $A$. fasciatus, slightly over $1 \frac{1}{3}$ as long as broad and not quite $\frac{2}{3}$ the length of the'first cubital on the cubital vein. Hind wings with the transverse median ending much before the base of the cubitus; in $A$. fasciatus both veins are nearly interstitial.

Black. Mandibles except at base and apex, narrow anterior margin of clypeus, hind femora and hind tibiæ entirely, first two joints of hind tarsi partly, and spurs of the hind tibiæ, reddish brown. The apical margins of the first two abdominal tergites are very faintly suffused with brown. Wings subhyaline, with blackish veins, infuscated in their apical third.

Tegument impunctate. Body almost devoid of pubescence. A few erect hairs on the mandibles and clypeus and on the terminal segments of the abdomen. No sericeous pile; but a feeble, grey pruinosity covers the shining body and shows clearly that the specimen is in a very fresh condition.

Described from one female specimen collected by Mr. Birkman in Lee County, Texas, May, 1907. ${ }^{1}$

This species comes near the preceding (wheeleri) but is sufficiently distinct in the characters shown in the key.

\section{List of Nearctic Species.}

1. Aporinellus apicatus Banks, Journ. New York Ent. Soc. 19, 1911, p. 230.

Aporus apicatus Banks, ibid. 18, 1910, p. 126, $0^{7}$.

Type-locality: Claremont, Calif.

In Mr. Banks' collection there are also specimens from 1. Mus. Comp. Zoöl. Cambridge, No. 10757. 
National City, Calif. (Van Duzee Coll.) and Felton, Sa. Cruz Mts., Calif. (Bradley Coll.).

2. Aporinellus banksi sp. nov., 우 . Type-locality: Lee Co., Texas.

3. Aporinellus californicus Rohwer, Proc. U. S. Nat. Mus. 53, 1917, p. 240, 'o .

Type-locality: Alameda Co., Calif.

4. Aporinellus completus Banks, Bull. Mus. Comp. Zoöl. 61, 1917, p. 97, o o $\sigma^{7}$.

Type-locality: Lone Tree, Yakima River, Wash.

Also recorded from Thorp, Kittitas Valley, Wash. I have seen in Mr. Banks' collection a o from Boulder, Colo., September 8, 1908, on flowers of Helianthus pumilus (Rohwer Coll.).

5. Aporinellus fasciatus (F. Smith) Banks, Journ. New York Ent. Soc. 19, 1911, p. 231, 우 Rohwer, Hymenoptera of Connecticut, 1916, p. 631.

Aporus fasciatus F. Smith, Cat. Hym. Brit. Mus. 3, 1855,

p. 175, $\sigma^{7}$. Cresson, Trans. Amer. Ent. Soc. 1, 1867, pp. 137, $\sigma^{7}$ and 149, $\circ$; ibid. 4, 1872, p. 27, $\sigma^{7}$; Synopsis Hym. Amer. 1887, p. 273. Birkman, Ent. News 10, 1899, p. 244.

J. B. Smith, Insects of New Jersey 1910, p. 674 .

Pompilus unionis Dalla Torre, Cat. Hym. 8, 1897, p. 330.

Type-locality: Warm Springs, S. C.

This is a widely distributed species being known from the following states: New York, Massachusetts, Connecticut, New Jersey, Virginia, North Carolina, South Carolina, Georgia, Texas and Colorado.

6. Aporinellus ferrugineipes (Viereck) Banks, Journ. New York Ent. Soc. 19, 1911, p. 230, 우.

Aporus ferrugineipes Viereck, Trans. Amer. Ent. Soc. 32, 1906, p. 204, ㅇ. .

Type-locality: Clark Co., Kans.

In Mr. Banks' collection from Bayville, N. Y. (Banks Coll.) and Fedor, Lee Co., Texas (Birkman Coll.). I have also taken a $\%$ at Wharton, Wharton Co., Texas, June 24, 1917.

7. Aporinellus intermedius Banks, $q$. Will be shortly described in the Bull. Mus. Comp. Zoöl.

Type-locality: Owens River, Calif. 
8. Aporinellus laticeps Banks, Journ. New York Ent. Soc. 19, 1911, pp. 230 and 231, 9 . Type-locality: Boulder, Colo.

9. Aporinellus medianus Banks, Bull. Mus. Comp. Zoöl. 61, 1917, p. 97, 우.

Type-locality: El Cajon, Calif.

Also known from Los Angeles, Calif., and Mid. F. Kaweah R., Sequoia Nat. Pk., 1700 ft., Calif.

10. Aporinellus rufus Banks, Journ. New York Ent. Soc. 19, 1911, p. 230, ㅇ.

Type-locality: Boulder, Colo.

11. Aporinellus wheeleri sp. nov., $q$.

Type-locality: Stony Brook Reservation, Boston, Mass.

The following three Nearctic Psammocharids have been described under Aporus; since in my opinion they do not belong in Aporinellus Banks, their status may be briefly discussed.

Aporus magnus Banks, $1910,{ }^{1}$ is based on a $\sigma^{7}$ from Fedor, Lee County, Texas. Mr. Banks has informed me that he has transferred this to Pedinaspis, and after examining the type specimen I fully agree with him. The pronotum is very long, as long as the mesonotum and distinctly flattened above; the posterior margin of the propodeum is deeply emarginate but the lateral angles are not spinose nor conical. There are three cubital cells in the fore wings, all broadly open on the radial vein. Length $12 \mathrm{~mm}$.

Aporus minimus Cresson, 1872,2 was based on a $\sigma^{7}$ from Texas. I have not seen the type, but a $\sigma^{\text {T }}$ taken by Mr. Banks at Falls Church, Va., agrees perfectly with Cresson's description. It is about $3 \mathrm{~mm}$. long; the propodeum is very feebly emarginate behind, but there are no projecting lateral edges; the pronotum is convex. The venation of the fore wings is peculiar; the radial cell is long and narrow; there are two cubital cells, the second of which is scarcely half as long as the first, regularly trapezoidal, much narrowed on both sides on the radial vein; it receives the first recurrent vein near the first transverse cubital and the second recurrent about its middle. If this specimen represents the true Aporus minimus Cresson, the species will probably be placed in

1 Journ. New York Ent. Soc. 18, p. 126.

2 Trans. Amer. Ent. Soc. 4, p. 207. 
the European genus Aporus Spinola; its exact position, however, cannot be decided upon till the female is discovered.

Aporus rufiventris Cresson, 1872,1 is undoubtedly not an Aporinellus as can readily be seen from the description: it possesses three cubital cells in the fore wings and has the propodeum transversely wrinkled; the abdomen is entirely bright fulvo-ferruginous, sericeous. Mr. Banks, who once examined the type, informs me that it most probably belongs in Pedinaspis. It was described on a $\circ$ from Texas. Length about $7 \mathrm{~mm}$.

Several of the Psammocharids described from Mexico undoubtedly belong to Aporinellus and in some instances may even be identical with some of the species known from the United States.

Pompilus tceniatus $\mathrm{Kohl}^{2}$ from Orizaba, Mexico, certainly is an Aporinellus. There are two cubital cells and the author writes in the description: "Mittelsegment beiderseits zahnförmig ausgezogen und zeigt genau die Bildung wie bei P.6-maculatus." The size, color and arrangement of the sericeous pubescence are similar to those of $A$. ferrugineipes (Viereck) with which this species is perhaps identical.

Pompilus (Aporus) yucatanensis Cameron ${ }^{3}$ of North Yucatan, Mexico, is said to have "the median segment rather long; the apex oblique, at the sides projecting into stout teeth-like processes. . . . The fore wings with only two cubital cellules." Undoubtedly an Aporinellus and perhaps not specifically different from $A$. fasciatus.

Pompilus (Aporus) decorus Cameron, $P$. monticola Cameron, $P$. flavomarginatus Cameron and P. (Aporus) smithianus Cameron, ${ }^{4}$ all of Mexico, apparently are not true Aporinellus though possessing two cubital cells in the fore wings.

1 Trans. Amer. Ent. Soc. 4, p. 207.

2 Verh. zool.-bot. Ges. Wien 36, 1886, pp. 315 and 336 .

3 Biologia Centr. Amer. Hymenoptera 2, 1893, p. 189.

Op. cit. pp. 190-191. 

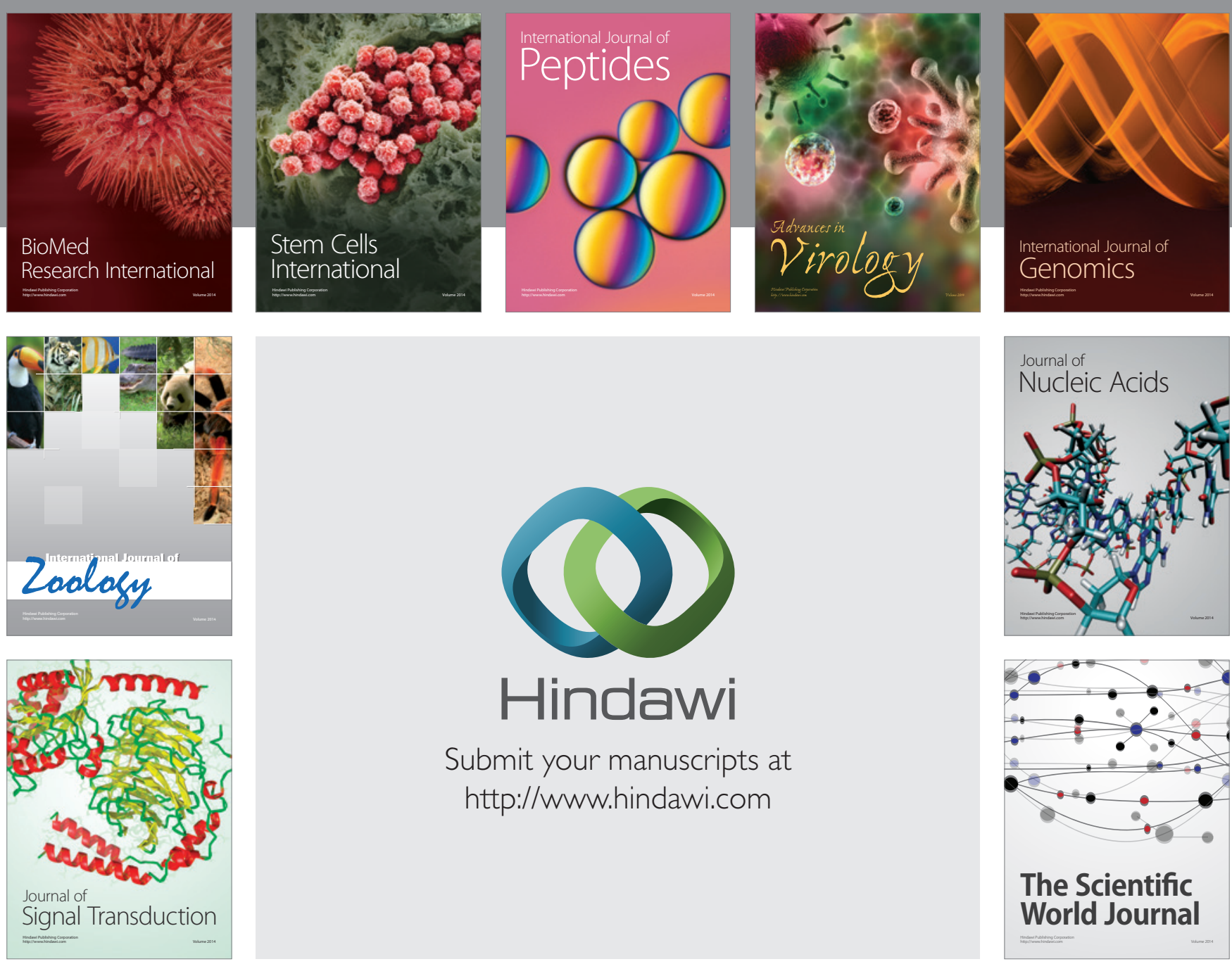

Submit your manuscripts at

http://www.hindawi.com
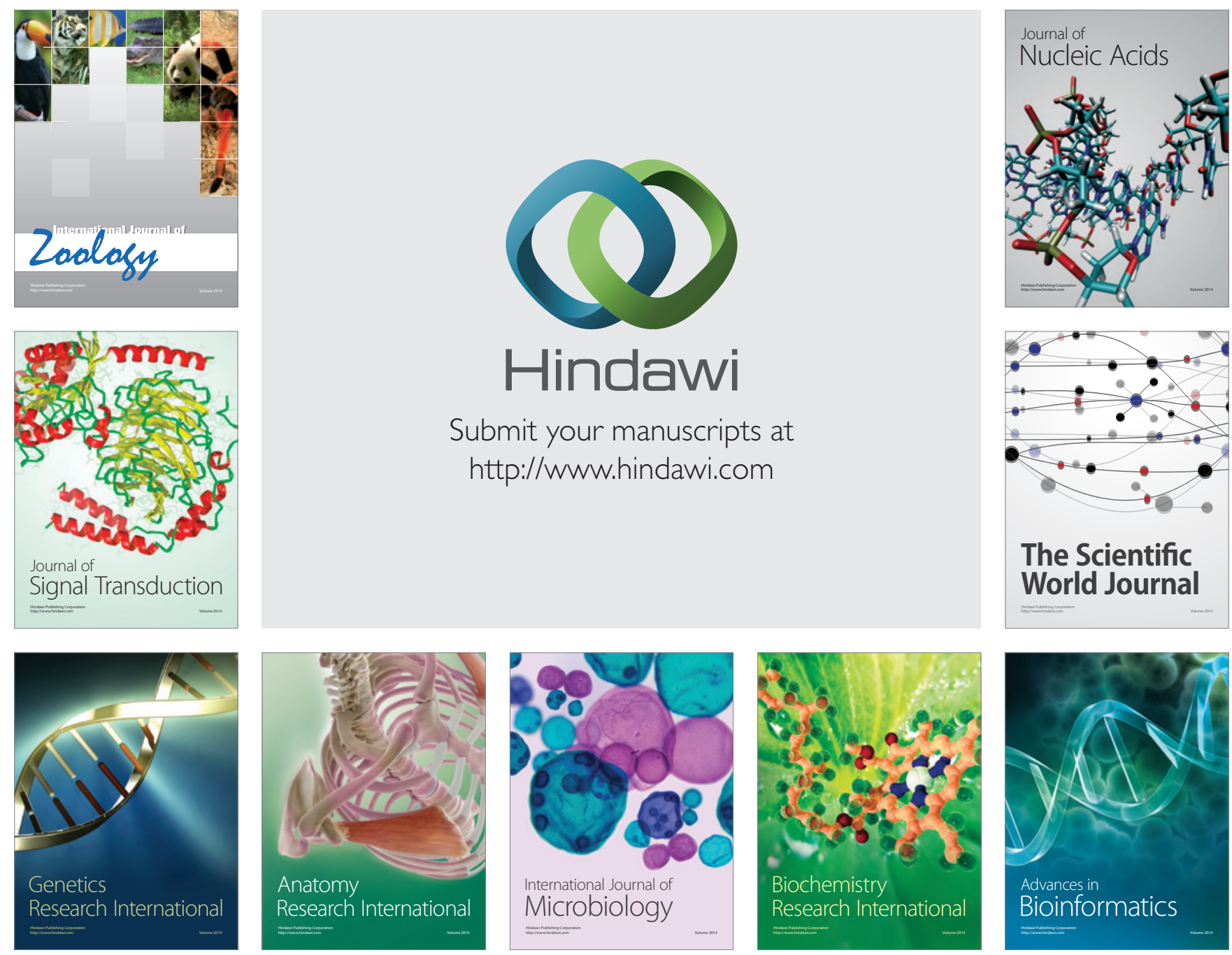

The Scientific World Journal
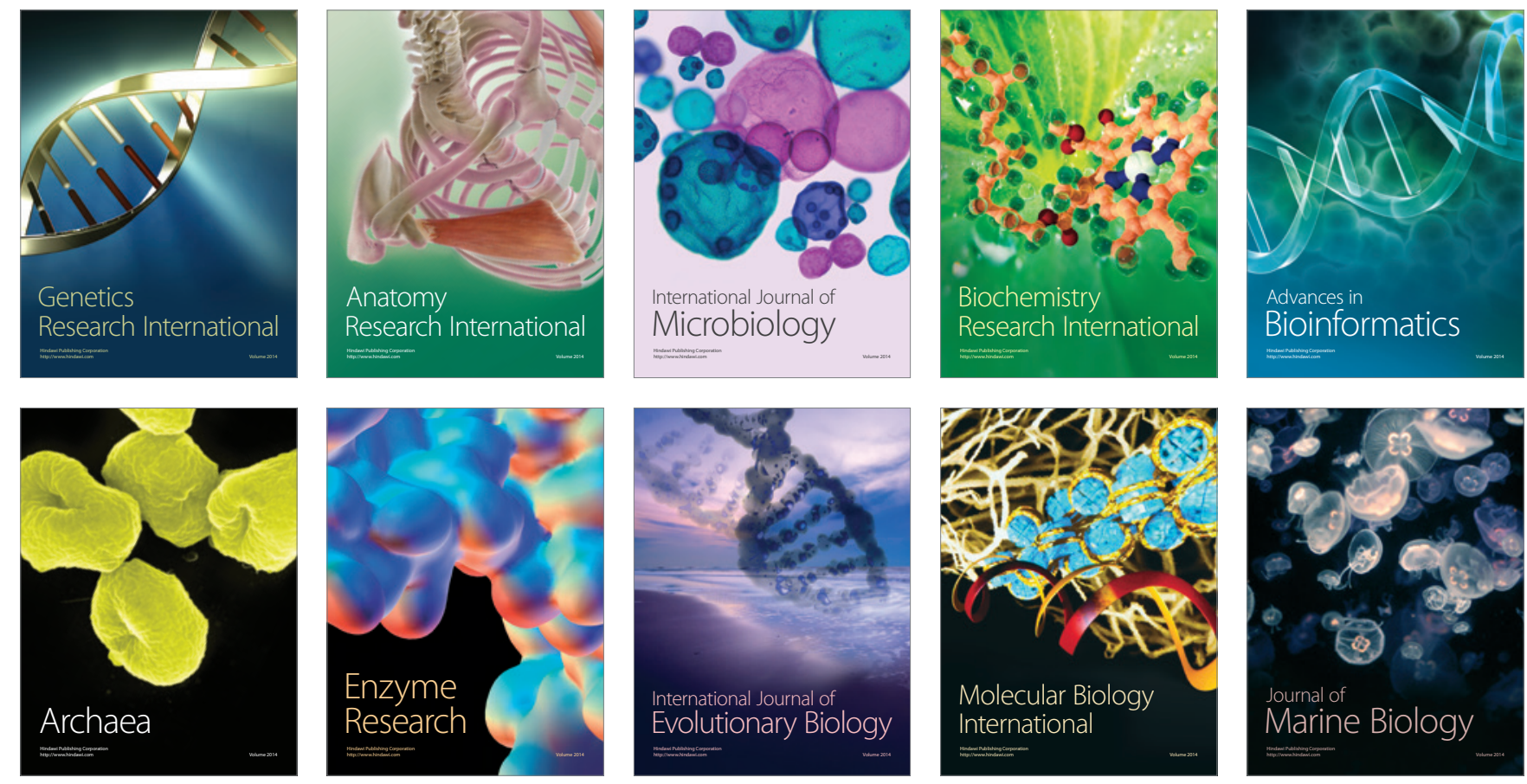